\title{
THE PHAEOSPHAERIA LEAF SPOT OF MAIZE IN BRAZIL: EVIDENCES OF A NEW ETHIOLOGIC AGENT
}

\author{
ELIZABETH DE OLIVEIRA ${ }^{1}$, FERNANDO TAVARES FERNANDES $^{1}$, ENIA MARA CARVALHO $^{2}$, \\ JOSÉ DA CRUZ MACHADO² \\ ${ }^{1}$ Pesquisadores, Embrapa Milho e Sorgo. Caixa Postal 151, CEP 35701-970 Sete Lagoas, MG. E-mail: \\ beth@cnpms.embrapa.br (autora para correspondência); tavares@cnpms.embrapa.br \\ ${ }^{2}$ Professor, Depto de Fitopatologia da Universidade Federal de Lavras. Caixa Postal 37, CEP 37200-000 Lavras, MG. \\ E-mail:machado@ufla.br
}

Revista Brasileira de Milho e Sorgo, v.3, n.3, p.343-356, 2004

\begin{abstract}
Phaeosphaeria leaf spot of maize" is a common and very important disease in Brazil. This disease was first described in India, and it was assumed to be caused by the fungus Phaeosphaeria maydis f. imp. Phyllosticta sp. However, in Brazil, several inoculations of this fungus in maize have not been successful on symptom developing. In addition, characteristic structures of $P$. maydis or Phyllosticta, perithecia or picnidia, respectively, are hardly seen on lesions of that disease. Eighty samples of "Phaeosphaeria leaf spot of maize" were collected between September 2000 and February 2004 and analyzed by scanning electron microscopy to check fungal structures presence. The lesions were also analyzed under light microscopy, and by transmission electron microscopy. In some cases, diseased leaf fragments were incubated on PDA medium or water-agar to observe growth of the isolated fungi. P. maydis or Phyllosticta sp perithecia or picnidia, respectively, were never found in the analyzed samples. A very thin hyphae (diameter less than $2 \mu \mathrm{m})$ and small structures identified as sporangia (23,9 $\mu \mathrm{m}$ diam.), zoosporos (3,2-3,5 $\mu \mathrm{m} \times 1,7-2,0 \mu \mathrm{m})$ and oocito $(10,4 \mu \mathrm{m}-12,5 \mu \mathrm{m}$ diam.) were present in $100 \%$ of the examined lesions. Based on those facts and considering that the fungus did not grow on PDA medium, making the application of Koch's Postulates difficult, the possibility of such fungus to be considered the ethiologic agent of that disease is quite high. Apparently, this fungus is a new species in Peronosporaceae, possibly genus Sclerophthora. However, confirmation of that hypothesis requires the development of additional studies.
\end{abstract}

Key words: Sclerophthora, Peronosporaceae, sporangium, zoospores, Phyllosticta.

\section{A MANCHA DE PHAEOSPHAERIA MAYDIS EM MILHO NO BRASIL: EVIDÊNCIAS DE UM NOVO AGENTE ETIOLÓGICO}

RESUMO - A "Mancha por Phaeosphaeria em milho" é uma doença comum e muito importante no Brasil. Essa doença foi descrita pela primeira vez na Índia, tendo sido constatado como agente causal o fungo Phaeosphaeria maydis f. imp. Phyllosticta sp. Contudo, no Brasil, inoculações destes fungos em milho não têm resultado no desenvolvimento de sintomas dessa doença. Ainda, as estruturas características desses fungos, peritécios e picnídios, são raramente encontradas nas lesões foliares. Oitenta amostras de lesões foliares da "Mancha por Phaeosphaeria em milho", foram coletadas em diferentes épocas no período de setembro de 2000 a fevereiro de 2004 e foram examinadas 
ao microscópio eletrônico de varredura para verificar a presença de estruturas fúngicas. As lesões foram também examinadas sob microscopia ótica e outras foram incubadas em meio BDA ou agar-água. Peritécios de P. maydis ou picnídios de Phyllosticta sp não foram encontrados nas lesões examinadas. Um fungo com hifas muito finas (diametro inferior a $2 \mu \mathrm{m})$ e pequenas estruturas identificadas como esporângio (23,9 $\mu \mathrm{m}$ diam.), zoosporos (3,2-3,5 $\mu \mathrm{m} \times 1,7-2,0 \mu \mathrm{m})$ e oocito $(10,4 \mu \mathrm{m}-12,5 \mu \mathrm{m}$ diam.), estava presente em $100 \%$ das lesões. Este fungo não cresceu em meio BDA e por essa razão o postulado de Kock não foi testado. Contudo, a possibilidade de ser esse fungo o agente etiológico da doença é elevada. Aparentemente, trata-se de uma nova espécie pertencente à família Peronosporaceae, e mais especificamente ao gênero Sclerophthora. Contudo, confirmações dessas hipóteses requerem ainda mais estudos, sobretudo sobre o papel que o referido organismo exerce no ciclo da doença, nas condições brasileiras.

Palavras-chave: Sclerophthora, Peronosporaceae, esporângio, zoosporos, Phyllosticta.

Phaeosphaeria leaf spot of maize was first described in India in 1965, as a "common disease in areas of Sikkim, Falimpong, West Bengal and The Tarai of Uttar Pradesh, and in the rainfall areas in and adjacent to the foothills of the central and eastern Himalayas" (Rane et al. 1965). The symptoms and signs of this disease were described as follows: "spots initially appear as small pale green of chlorotic areas which enlarge, becoming bleached or appearing dried and surrounded by brownish margins. The spots are round, elongate to oblong in shape, measuring 0,3 to $2,0 \mathrm{~cm}$, and are scattered over the leaf. Infrequently, the spots coalesce and become irregular in shape. Perithecia and, less frequently, pycnidia develop in the lesions." According to the authors, cultures of the fungus were established from ascospores and pycnidia identical to those studied from original leaf collections, developed abundantly in these cultures. The pycnidial stage was found to belong to the genus Phyllosticta and the koch's Postulate was proven to this fungus. After reviewing the identification and nomenclature for the perfect stage of this fungus, the authors proposed Phaeosphaeria maydis as a new combination and Sphaerulina maydis P. Hennigs in Hedvigia, 41:
302, 1902 and Leptosphaeria zae-maydis Saccas in Rev. Patho. Veg. 30: 179, 1951 as synonyms. They supposed that the fungus described as Sphaerulina maydis on maize leaves in Brazil (Hennings, 1902) could be the same fungus isolated in India, even though the type of $S$. maydis had not been examined. Indeed, among several fungal species in collection in São Paulo State (Brazil), Hennings described S. maydis based on exam of perithecia present on "maculis rotundatis, pallidis, exaridis, zona bruneola cinctis", without details of that "possible disease". Since Phaeosphaeria leaf spot of maize was described by Rane et al. (1965) its occurrence in Brazil has been reported in several publications (Balmer et al., 1970; Fernandes \& Sans 1994, Pinto, 1997; Pinto, 1999; Shuelter et al. 2003).

Phaeosphaeria leaf spot of maize is one of the most important maize diseases in Brazil, because under favorable conditions it causes severe losses, and it has been found disseminated in the main areas of maize growth (Fernandes \& Oliveira, 1997). However, the ethiological agent of this disease remains still questionable, and little conclusive. Under experimental conditions, from several inoculations attempts using spores or mycelium of $P$. maydis or Phyllosticta obtained 
from cultures, in maize, symptoms of "Phaeosphaeria leaf spot" disease have not been reproduced (Fernandes, F. T. data not published). Special conditions for inoculation of $P$. maydis in maize have been studied by Fantin \& Balmer, 1997, and some researchers have published papers about the disease, named "Phyllosticta leaf spot" since perithecia are hardly found on lesions compared to picnidia (Pinto, 1999). Based on the analysis of 2728 lesions of "Phaeosphaeria leaf spot of maize" from 79 maize hybrids, pycnidia and perithecia were found only in 11.5 and 10.6 $\%$ lesions, respectively, and in $3.1 \%$ together of the total lesions. From work of Paccola-Meirelles et al. (2001), a bacterial species was frequently isolated from lesions of "Phaeosphaeria leaf spot" in maize, and caused symptoms similar to that disease which was reported as the result of maize seedlings inoculation. However, it is important to consider that under field conditions, symptoms of "Phaeosphaeria leaf spot of maize" start only after maize flowering (Fernandes \& Oliveira, 1997).

In view of all those findings and doubts, the aim of this study was to examine "Phaeosphaeria leaf spot of maize" lesions under light and electron microscopy, to check out the presence of fungi and/or bacteria as possible ethiologic agents of this important disease.

\section{Material and Methods}

"Phaeosphaeria leaf spot of maize in Brazil": characterization of symptoms and disease development - Symptoms and signals usually start after maize flowering more frequently during grain development. The first lesions can be observed in lower leaves, and under favorable conditions the disease progress up to the upper leaves. The severity of symptoms depends on the susceptibility of the maize genotype, in those more susceptible cultivars the diseased leaves dry up before maturity. Young lesions are green pale to brownish soaked that enlarge and become pale light dried spots. Both young and older spots are usually round to a little bit elliptical, scattered on the leaf surface, with few cases of coalescence. The size of spots is variable from 0,3 up to $2,0 \mathrm{~cm}$. For some maize genotype very susceptible materials, lesions can be larger than $2,0 \mathrm{~cm}$ becoming irregular, with an "elliptical outline" (Figure 1).

Sampling and analyses - From September 2000 to February 2004, diseased leaves of different maize genotypes were collected in different months, during summer and autumn maize-growing-season, at the Embrapa Experimental Farm in Sete Lagoas, Minas Gerais. Those samples were used for examination under light and electron microscopy and for access fungal structures and isolation in culture.

Scanning electron microscopy (SEM) - Small fragments (around 0,3 x 0,5cm) of "Phaeosphaeria leaf spot of maize" lesions were cut and fixed in Millonigs fixative overnight at $4^{\circ} \mathrm{C}$, and post fixed for $1 \mathrm{~h}$ in osmium tetroxide (2\%). Those fragments were dehydrated by successive immersion in alcohol-acetone $(25,50$, $75 \%$ ) and acetone $100 \%$, for $20 \mathrm{~min}$ each concentration, then dried in critical point drier and coated with gold under sputter coater, before fixing on stubs for SEM analysis. A total of 80 samples, including young and old lesions, were analyzed by SEM.

Transmission electron microscopy (TEM) - Ten small pieces (around 0,1 x 0,2cm) of "Phaeosphaeria leaf spot of maize" lesions, fixed and dehydrated as described before, and embedded in spurr resin. Thin sections obtained with ultramicrotome were stained with uranil acetate and lead citrate for TEM analysis (Hayat, 1989). 

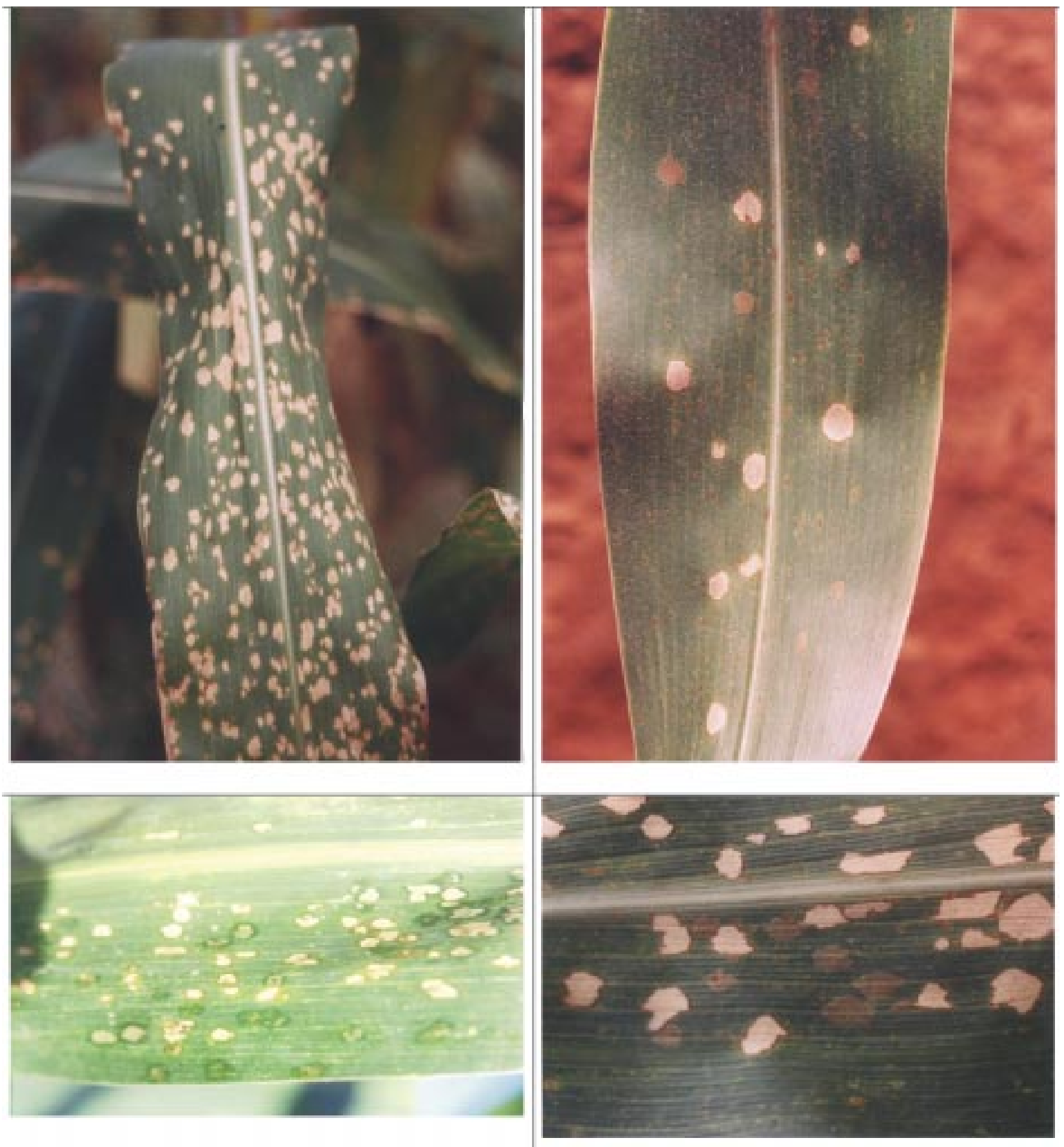

FIGURE 1. Lesions of "Phaeosphaeria leaf spot in maize" in Brazil.

Light microscopy - A total of 80 slides containing fresh fungal structures, removed samples, including young and old lesions, were from lesions under stereo microscopy, using directly analyzed under stereo and optical lactophenol or tripan blue in lactophenol $0,1 \%$ microscopy. For optical microscopy, several glass were examined. In addition, small pieces of 
necrotic and chlorotic (and soaked) areas of diseases leaves were examined after heating, and staining with Aman"s blue $(0,1 \%)$ to observe hypha and other structures inside tissues.

Incubation "in vitro" - A total of 50 fresh lesions of "Phaeosphaeria leaf spot of maize" were surface sterilized by immersion in chloramine $\mathrm{T} 1,5 \%$ for $10 \mathrm{~min}$ and rinsed three times with sterilized water, followed by incubation in Potato Dextrose Agar (PDA) medium, at $25^{\circ} \mathrm{C}$ with photoperiod of $12 \mathrm{~h}$ light and $12 \mathrm{~h}$ dark. Some spherical structures found on lesions were also removed with forceps and incubated in water drops in special glass slides. Other spherical structures removed from lesions were incubated on water-agar 1\% in Petri Dish.

\section{Results}

Scanning electron microscopy (SEM) - In all samples analyzed, perithecia of Phaeosphaeria maydis and pycnidia of Phyllosticta sp were never found. A few structures similar to conidia of Exerohilum sp or Alternaria $\mathrm{sp}$ scattered on the lesion were sometimes observed.

However, structures of a fungus looking like a member of the Division Mastigomycotina were found growing in all samples examined at variable intensities. Several of those structures, identified as part of the life cycle of this species, were recognized as follows: 1- Sporangium produced at the top of a single sporangiophore; round shaped (diameter $23,9 \mu \mathrm{m}$ ), with round operculi, ornamented with spines (Figure 2). Collapsed sporangia presented diameter with variable size, from 11,74 to $19,70 \mu \mathrm{m}$; 2 -

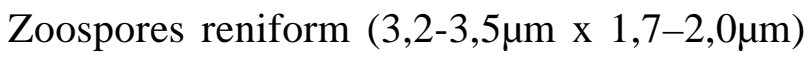
with remaining flagela (Figure 3); 3- Oocyte with ornamentate wall (diameter $10,4 \mu \mathrm{m}-12,5 \mu \mathrm{m}$ ) (Figure 4); 4- Hypha very thin (diameter 1,4 $\mu \mathrm{m}$ up to $2,0 \mu \mathrm{m}$ ), without visible septa, except at the base of sporangiophore; several branches, frequently penetrating through stomata. Mycelium development was most frequent on and under cuticula (Figure 5).

The simultaneous occurrence of the thin mycelium with at least one reproductive structures (sporangium, oocyte) as described above, was confirmed in $100 \%$ of all analyzed samples. In general, development of this fungus was more intense in younger lesions than in older ones.

Two different structures that might be related with oogonia and antheridium (oocyte producing) found associated to leaf spots in the present case, were not completely understood (Figure 6). Those structures were not found so frequently like those ones showed in Figures 2, 3,4 and 5 .

Transmission electron microscopy (TEM) - No bacteria cells or septate hyphae were observed in the thin sections of lesions examined. Only a very thin hypha ( $215 \mathrm{~nm}$ diameter) without septa was observed inside deteriorated mesophyll cells.

\section{Light microscopy - Under} stereomicroscopy, it was possible to observe small light pink or light yellow "small-bolls" (Figure 7) which were removed and mounted on glass-slides with water or lactophenol for observation under microscopy with magnification $400 \mathrm{X}$. At this resolution, it was possible to distinguish a hyaline round structure ornamentate with little spines. This kind of structure was considered the same sporangium as observed under scanning microscopy (Figure 8).

Although it is very difficult to observe hypha with a diameter smaller than $2 \mu \mathrm{m}$ under optical microscopy, a very thin blue-stainedhypha was observed with objective $400 \mathrm{X}$ on 


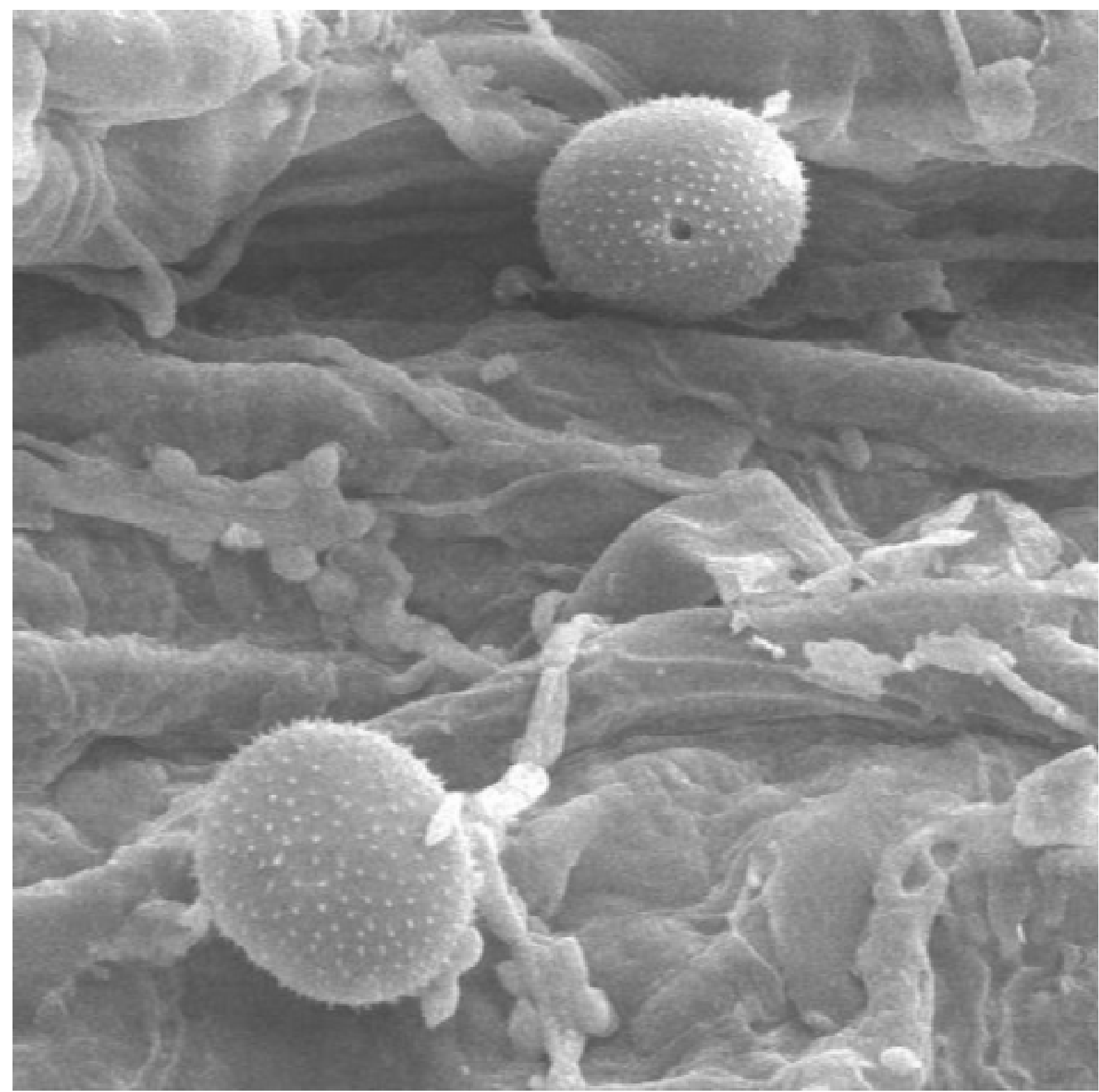

FIGURE 2. Sporangium, SEM, 1000X.

lesions submitted to lactophenol clearing (Figure 9,10$)$. In the same lesions, septate hypha, of other fungi, were also present, but in low frequence.

Incubation "in vitro" - The fungus Phaeosphaeria maydis was never isolated from lesions incubated in PDA medium. Isolation of the fungus producing structures like sporangium, oocyte and zoospores as observed on lesions at the SEM or light microscopy was not successful in this study. In water-agar medium at least one spherical structure similar to a vesicle was produced, 2 days after incubation. That "vesicle" had almost the same size of the original spherical 


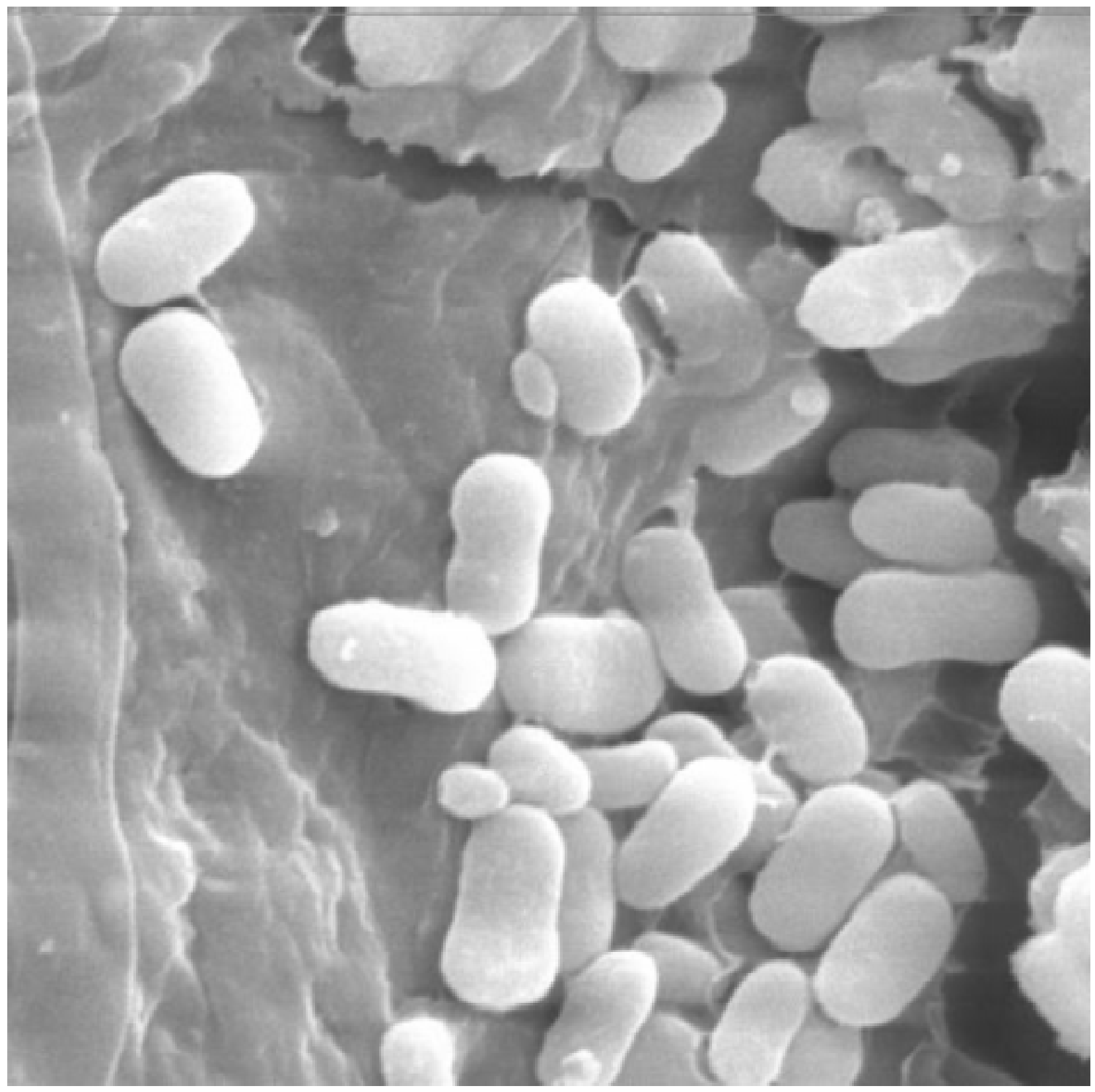

FIGURE 3. Reniform zoospores with remaining flagela. SEM, 5000 X.

structure. Inside water drop on glass slide preparation small moving structures like zoospores were seen after 2 days.

\section{Discussion}

Since perithecia of $P$. maydis or picnidia of Phyllosticta sp were not found in the eighty samples analyzed by scanning electron microscopy, it is most likely that this fungus is not the ethiological agent of "Phaeosphaeria leaf spot of maize", in Brazil. This hypothesis could be supported by Paccola et al. (2000) who found those structures only in approximately $11 \%$ of a total 2.728 lesions examined under light 


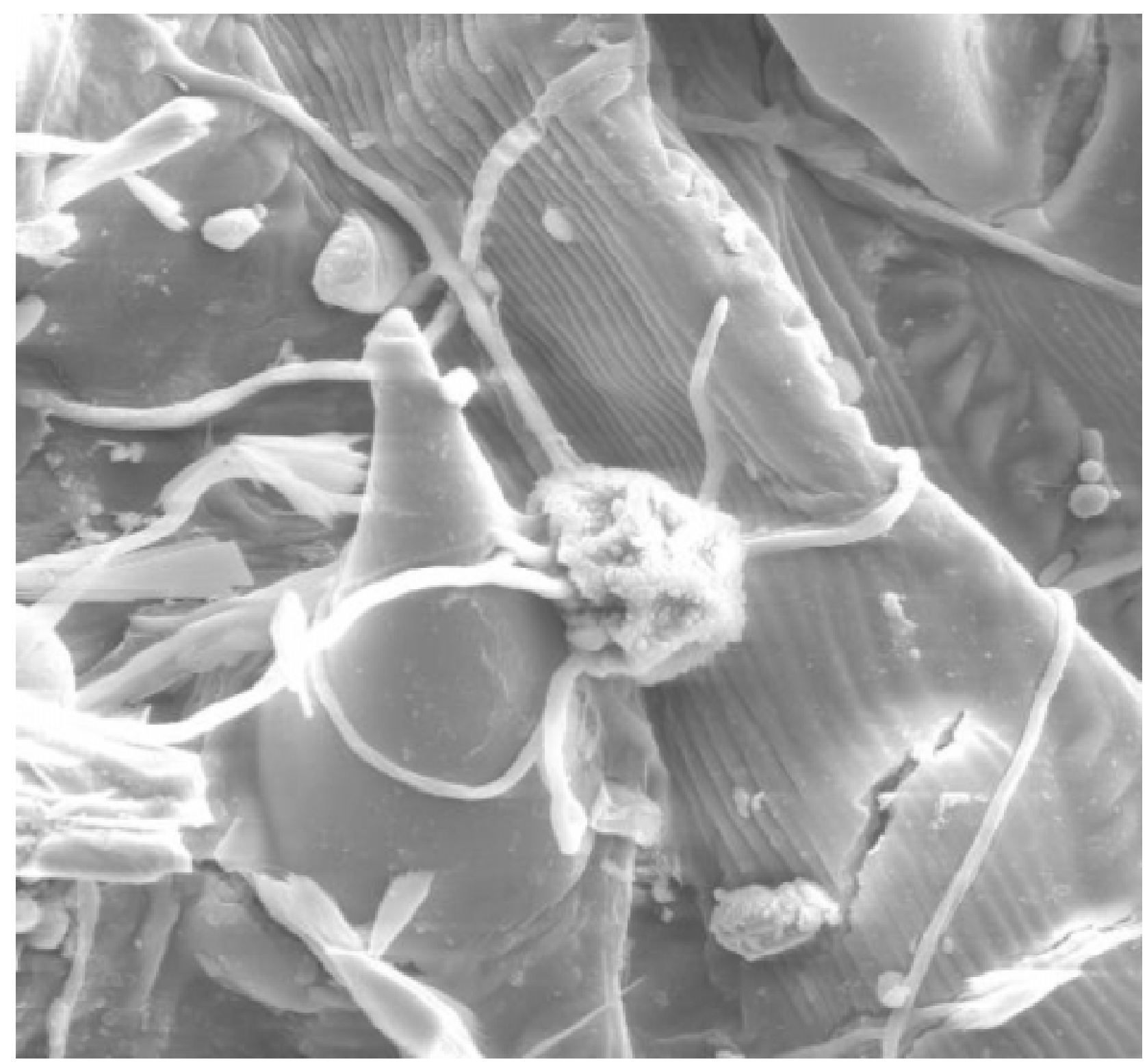

FIGURE 4. Germinating oocyte; hypha extending on lesion surface, and on leaf hair (left). SEM $1000 \mathrm{X}$.

microscopy. On the other hand, this new and not completely identified fungus suspected to belong to Peronosporaceae-Sclerophthora, was found associated to all samples analyzed by SEM, and could be considered to an extent as the ethiological agent of that disease. The main reason for not reporting this fungus on lesions of that disease earlier could be the small size of its structures, with very thin hypha, almost impossible to be observed under light microscopy. In addition, as this fungus does not grow on PDA medium, it becomes difficult to isolate it for Koch Postulate test and other studies.

In addition to the morphological aspects, another important evidence supporting the hypothesis of a new ethiological agent for the leaf spot disease in maize, described as caused by Phaeosphaeria and its imperfect stage 


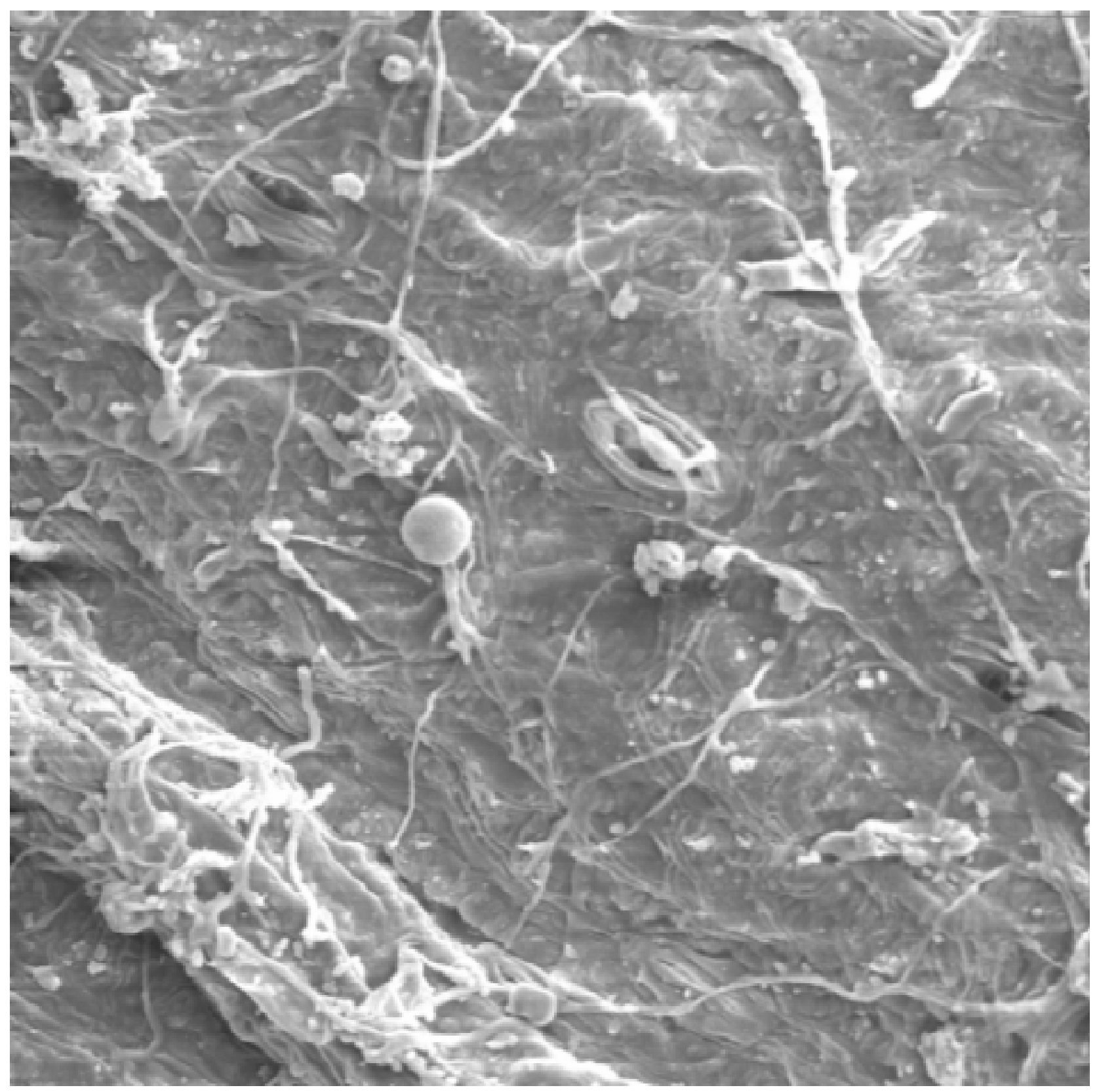

FIGURE 5. Mycelium on and under cuticula, SEM.

Phyllosticta, is the fact that fungicides of the groups benzimidazol and triazol did not provide good control of the disease when they were tested on developing plants of maize in the field (Pinto 1995, Pinto 2003). As it is well-known, none of those fungicides is expected to affect species belonging to Oomycota (Andrei, 1999; Andrei, 2003). On the other side products of the groups dithiocarbamate (ex. Mancozeb) and copper fungicides are reported to be efficient in controlling such disease in Brazil (Pinto, 1999). Investigation of fungicides specific to Oomycota members in 


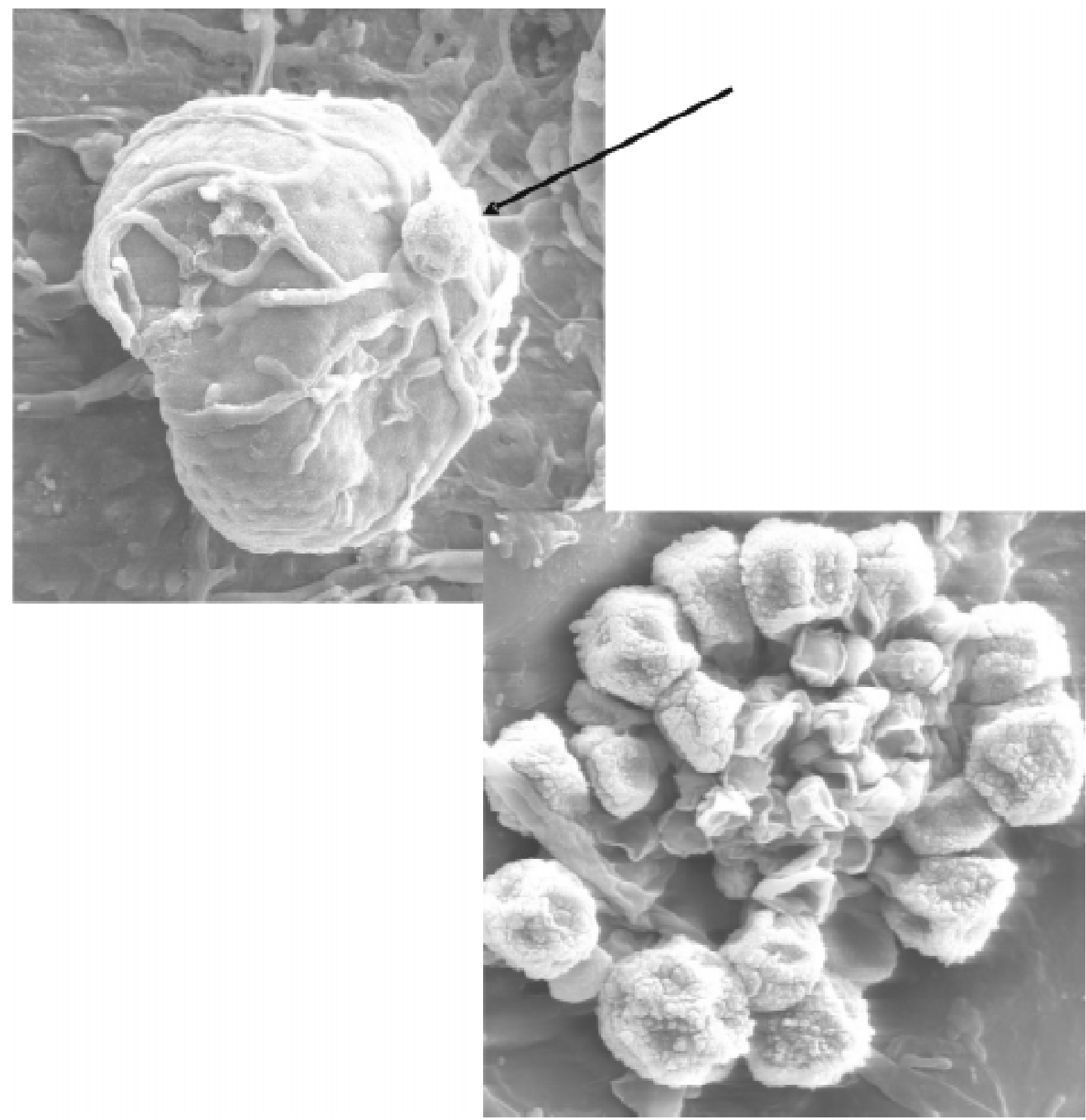

FIGURE 6. A) SEM, 1000X, one oogonia $x$ antheridium?; B) SEM 2000X, many oogonia $x$ antheridium?

the control of such disease in one of the next steps to be considered in the attempt to check up the identity of the ethiologic agent in that case.

Additional evidence supporting the hypothesis that the disease under discussion may be caused by a member of Oomycota is that the favorable conditions for the development of the disease in Brazil are: temperatures around $15^{\circ} \mathrm{C}$ at night and high air humidity (Fernandes \& Sans, 1994). Under those conditions, most downy 


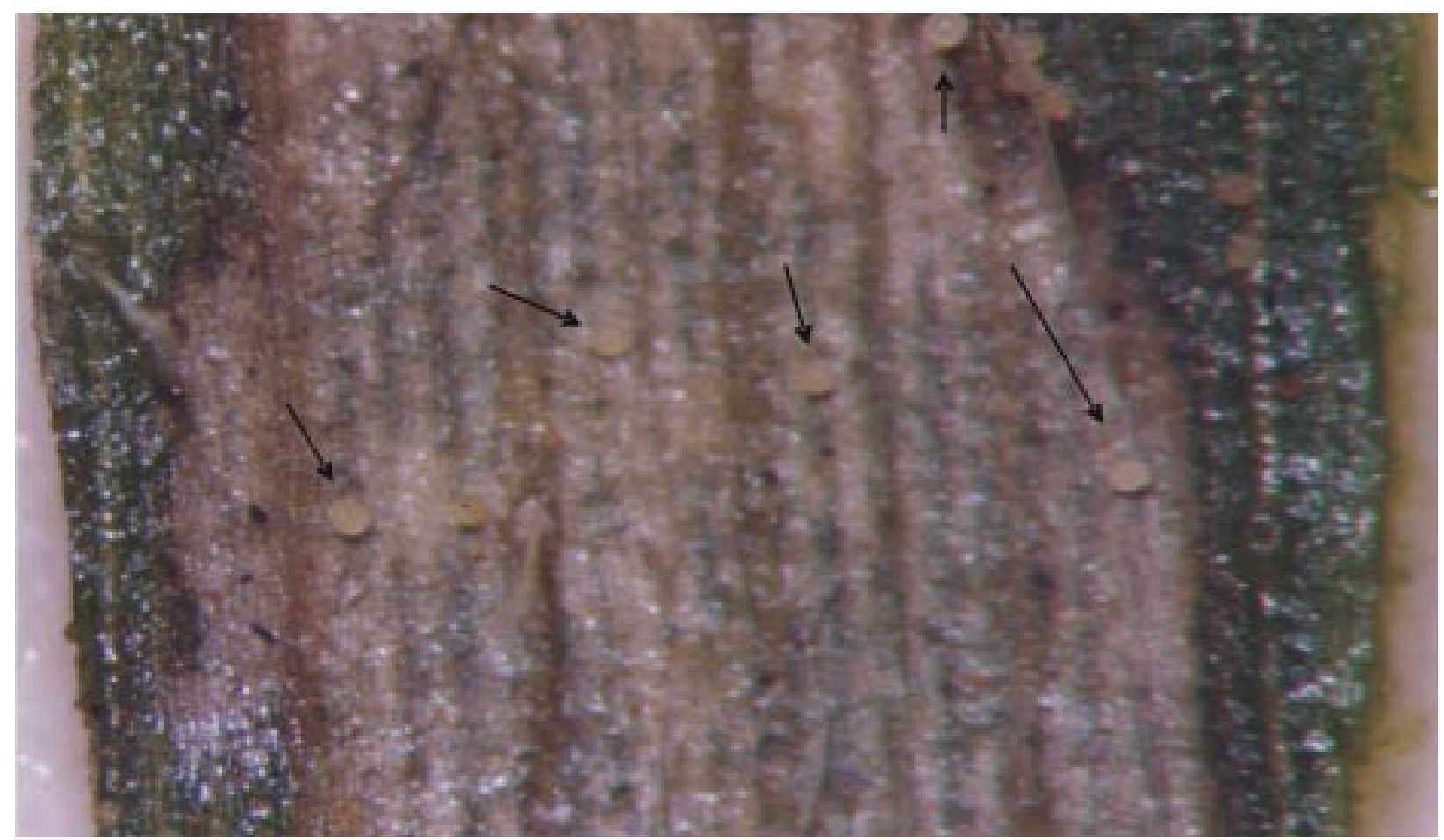

FIGURE 7. Sporangium under stereomicroscopy (80X).

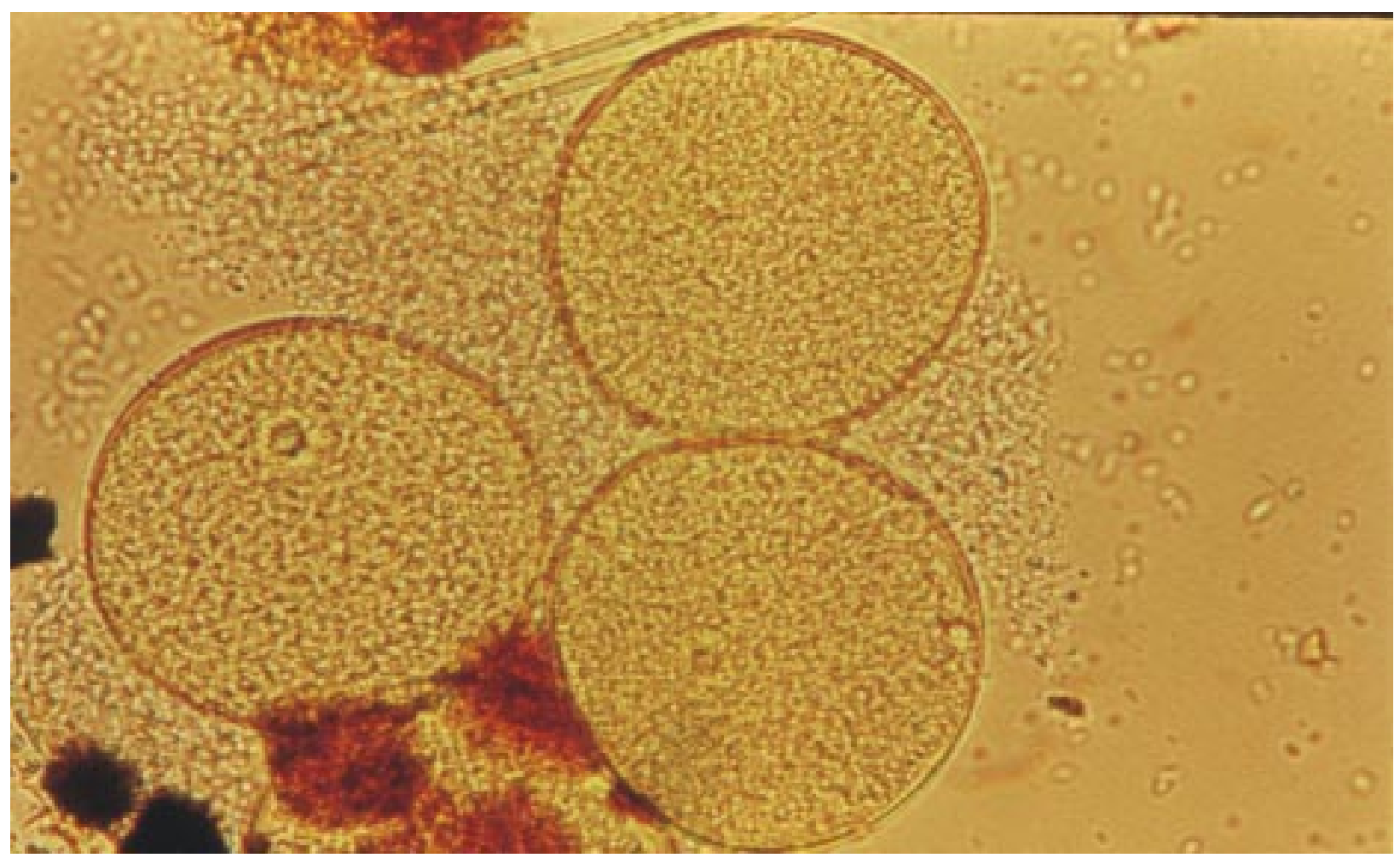

FIGURE 8. Sporangia, and zoosporos (?) under optical microscopy; 400X.

Revista Brasileira de Milho e Sorgo, v.3, n.3, p.343-356, 2004 


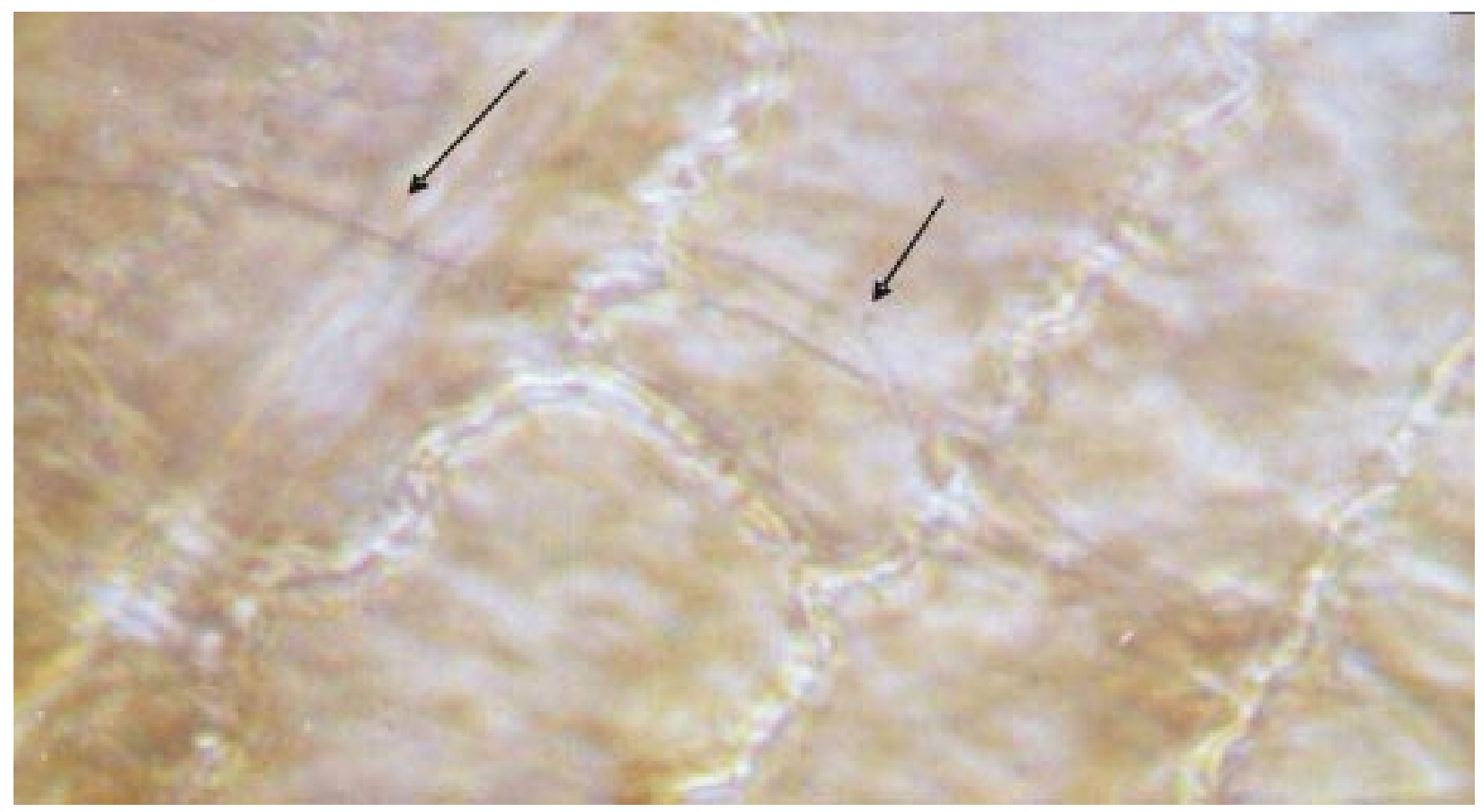

FIGURE 9. Blue stained no septate hyphae on lesions of "Phaeosphaeria leaf spot of maize". Light microscopy, 400X.

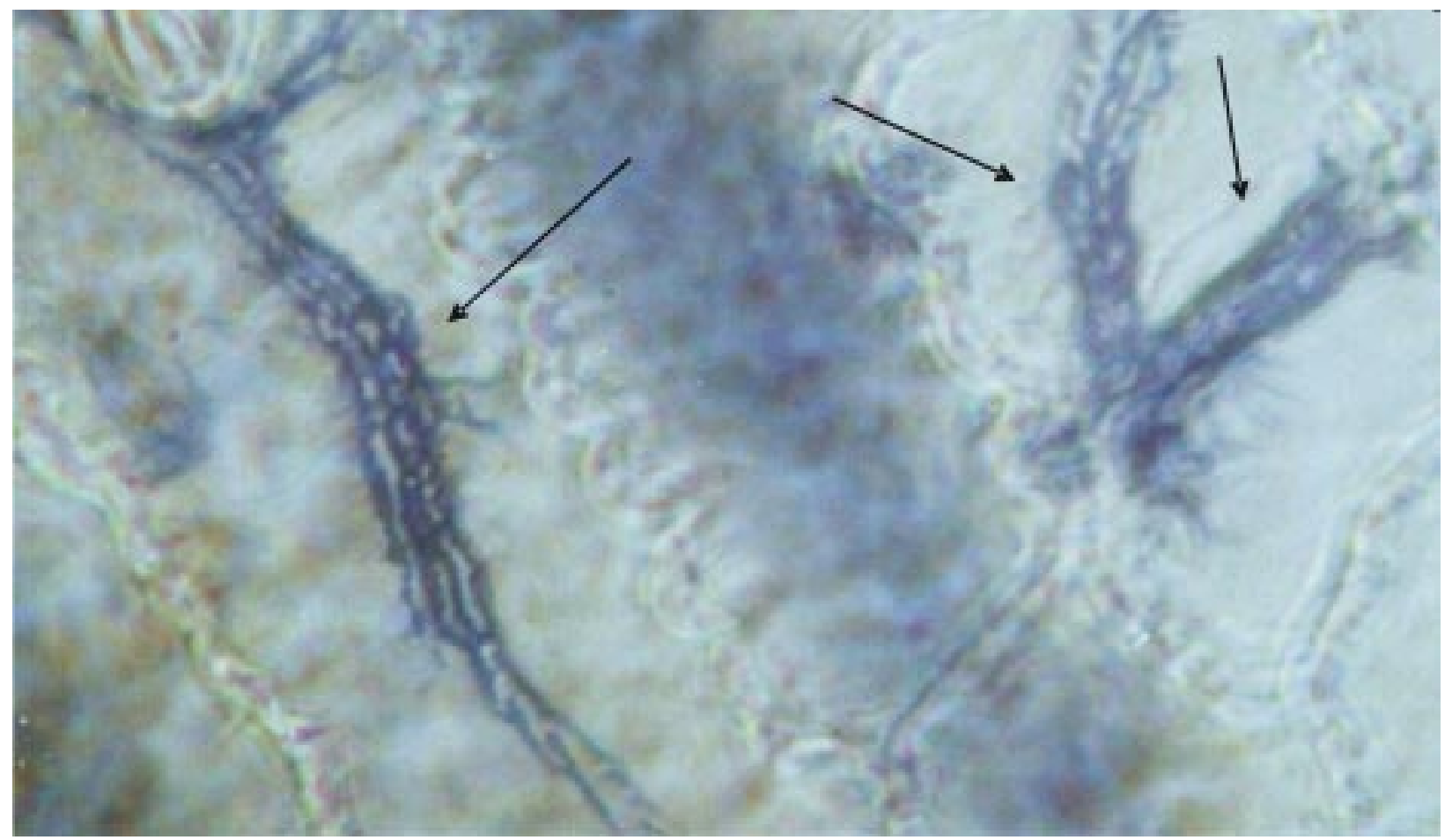

FIGURE 10. Blue stained mycelium with thin hyphae on lesions of "Phaeosphaeria leaf spot of maize". Light microscopy, 400X. 
mildew diseases are reported to be favored (Agrios, 1988).

Based on classical references, such as Ainsworth et al. (1973), and Alexopoulos (1996) the morphological observations in this study suggest that the structures associated to the lesions examined are typical members of the Peronosporales order that belongs to Oomycota Group.

Whether the organism in focus belongs to one or to other family of Peronosporales, considering the huge variation of structures observed in this study, is a matter to be further investigated. The typically biotrofic nature of all species of Sclerophthora on Graminae, as reported by Ainsworth et al. (1973); Shaw (1978) may be an indication that the organism observed on leaf spot lesions in maize in Brazil may be a new species of that genus.

\section{Conclusions}

Pherithecia of Phaeosphaeria. maydis and picnidia of Phyllosticta sp are not common on lesions of "Phaeosphaeria leaf spot of maize" disease.

An organism, looking like a Peronosporaceae-Sclerophthora that does not grow on PDA medium, is present in all lesions of "Phaeosphaeria leaf spot of maize" disease.

The real identity and role of this new organism as ethiologic agent of "Phaeosphaeria leaf spot of maize" disease in Brazil, are important aspects to be investigated next to confirm the findings of this study.

\section{References}

AGRIOS, G. N. Plant pathology. San Diego: Academic Press, 1988. 803 p.

ALEXOPUlOS, C. J.; MIMS, C. W.; BLACWELL, M. Introductory mycology 4.ed. New York: J. Wiley, 1996. 869 p.
ANDREI, E. (Coord.) Compendium de defensivos agrícolas: guia prático de produtos fitossanitários para uso agrícola, 6 ed. ver. atual. São Paulo: Organização Andrei, 1999. 672 p.

ANDREI, E. (Coord.) Compendium de defensivos agrícolas: guia prático de produtos fitossanitários para uso agrícola, 6 ed. ver. atual. São Paulo: Organização Andrei, 2003. v.2. Complemento de atualização.

AINSWORTH, G. C.; SPARROW, F.K.; SUSSMAN, A. S. The fungi an advanced treatise. New York: Academic Press, 1973. v. IVB: A taxonomic review with keys: Basidiomycetes and lower fungi. 504 p.

BALMER, E. Doenças do milho. In: GALLI, F. (Coord.) Manual de Fitopatologia: doenças das plantas cultivadas. São Paulo: Agronômica Ceres, 1980. cap. 27, p371-391.

FANTIN, G. M.; BALMER, E. Método de inoculação e evolução de sintomas da Mancha Foliar de Phaeosphaeria maydis em milho. .Summa Phytopatologica, Jaboticabal, v. 23, n.1, p. 70, 1997. Edição de Resumos do XX Congresso Paulista de Fitopatologia, São Paulo, 1997.

FERNANDES, F. T.; OLIVEIRA, E. Principais Doenças na Cultura de Milho. Sete Lagoas: EMBRAPA-CNPMS, 1997. 80 p. (EMBRAPACNPMS. Circular Técnica, 26).

FERNANDES, F. T.; SANS, L. M. A. Influência das condições climáticas na ocorrência das lesões foliares por Phaeosphaeria maydis. In: CONGRESSO NACIONAL DE MILHO E SORGO, 20, 1994, Goiânia. Resumos... Goiânia, GO. ABMS/EMGOPA/EMBRAPA-CNPMS/ UFG/ Emater-GO, 1994. p. 136. 
HAYAT, M.A. Principles and techniques of electron microscopy: biological applications. 3.ed. Boca Raton: CRC Press, 1989. 469 p.

HENNINGS, P. V. Fungi S. Paulenses II a cl. Puttemans collecti. Hedwigia, Dresden, v. 41, p. $295-311,1902$.

PACCOLA-MEIRELLES, D. L., FERREIRA, A. S.,MEIRELES, W. F., MARRIEL, I. E., CASELA, C. R. Detection of a bacterium associated with a Leaf Spot Disease of maize in Brazil. Journal Phytopathology, Berlin, v. 149, p. 275-279, 2001.

PINTO, N. F. J. A.; FERNANDES, F. T. Avaliação de fungicidas no controle da mancha foliar do milho causada por Phyllosticta sp. (Phaeosphaeria maidis). Fitopatolologia Brasileira. Brasília, v. 20, p. 333, 1995, Suplemento.

PINTO, N. F. J. A. Eficiência de fungicidas no controle de doenças foliares do milho. Summa Phytopathologica, Piracicaba, v. 23, n. 3/4, p. 271-274, 1997.
PINTO, N. F. J. A. Eficiência de doses e intervalos de aplicações de fungicidas no controle da Mancha-Foliar do milho provocada por Phaeosphaeria maydis Rane, Payak \& Renfro. Ciência e Agrotecnologia, Lavras, v. 23, n. 4, p. 1006-1009, 1999.

PINTO N. F. J. A. Controle químico de doenças foliares em milho. Revista Brasileira de Milho e Sorgo, Sete Lagoas, v. 3, n. 1, p. 134-138, 2004.

RANE, M. S.; PAYAK, M. M.; RENFRO, B. L. A. Phaeosphaeria leaf spot of maize. [s.1.]: Indian Phytopathological Society, 1965. 10 p. (Bulletin, 3).

SHAW, C. G. Peronosclerospora species and other downy mildews of the graminae. Mycologia, New York, v. 70, p. 594-604, 1978.

SHUELTER, A. R.; SOUZA, I. R. P.; TAVARES, F. F.; SANTOS, M. X. dos; OLIVEIRA, E.; GUIMARÃES, C. T. Controle genético da resistência do milho à mancha por Phaeosphaeria. Revista Brasileira de Milho e Sorgo, Sete Lagoas, v.2, n.1, p.80-86, 2003. 